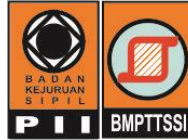

doi: mkts.v24i1.18175

\title{
Evaluasi Kinerja Campuran Beraspal dengan Bitumen Hasil Ekstraksi Penuh dari Asbuton
}

\author{
Nyoman Suaryana, "Iwan Susanto, Yohanes Ronny, Ida Rumkita Sembayang \\ Pusat Penelitian dan Pengembangan Jalan dan Jembatan, Kementerian Pekerjaan Umum dan \\ Perumahan Rakyat, Bandung \\ ${ }^{*}$ iwan.susanto@pusjatan.pu.go.id
}

Received: 21 Maret 2018 Revised: 13 Juli 2018 Accepted: 18 Juli 2018

\begin{abstract}
Asbuton is a natural rock asphalt that can be found on the island of Buton in Southeast Sulawesi province, has a large deposits but not yet well utilized. This research aims to find out the performance of asphalt mixtures AC-WC (Asphaltic Concrete Wearing Course) and HRS-WC (Hot Rolled Sheet Wearing Course) using bitumen results from full extraction of asbuton. The research was done by experimental methods through laboratory tests then its performance was compared to convensional mixtures using asphalt oil with penetration grade of 60. The results obtained showed that the bitumen of asbuton did not meet the specification of bitumen based on penetration grade. Characteristics of hot mixture asphalt using bitumen of asbuton showed better performance in terms of the Marshall stability namely $1871 \mathrm{~kg}$ higher than the convensional hotmixture of asphalt, with $1100 \mathrm{~kg}$ for AC-WC and $1241.9 \mathrm{~kg}$ compared with $1094 \mathrm{~kg}$ for HRS-WC. In addition, the results of deformation resistance tests showed asphalt mix with pure asbuton more resistant to rutting shown by higher dynamic stability value namely 4200 track/mm compared with 492 track/mm for AC-WC and 2739 track/mm compared with 325 track/mm. The modulus resilient value of mix with pure asbuton is also higher at temperature of $25^{\circ} \mathrm{C}$ and relatively the same-at temperatures of $35^{\circ} \mathrm{C}$ and $45^{\circ} \mathrm{C}$. While the resistance of fatigue for $A C$-WC and HRS-WC on the test tensile strain of $150 \mu s$ were relatively the same as hotmix asphalt using asphalt oil penetration grade of 60, but on test of a larger tensile strain has worse fatigue resistance, especially for $A C$-WC.
\end{abstract}

Keywords: Asbuton, full extraction, resilient modulus, stability, fatigue

\begin{abstract}
Abstrak
Asbuton yang merupakan aspal alam di Pulau Buton, Provinsi Sulawesi Tenggara mempunyai deposit yang melimpah, namun pemanfaatan potensi tersebut belum maksimal. Penelitian ini bertujuan untuk mengetahui kinerja campuran beraspal AC-WC (Asphaltic Concrete Wearing Course) dan HRS-WC (Hot Rolled Sheet Wearing Course) dengan menggunakan bitumen hasil ekstraksi penuh dari asbuton. Penelitian dilakukan dengan metode eksperimen melalui pengujian di laboratorium dan hasilnya dibandingkan dengan kinerja campuran beraspal konvensional yang menggunakan aspal minyak penetrasi 60. Berdasarkan hasil analisis uji karakteristik bitumen, menunjukan aspal hasil ekstraksi asbuton tidak memenuhi kriteria spesifikasi aspal berdasarkan kelas penetrasi. Karakteristik campuran dengan asbuton murni mempunyai kinerja yang lebih baik ditinjau dari nilai stabilitas Marshall yang lebih tinggi yaitu $1871 \mathrm{~kg}$ berbanding $1100 \mathrm{~kg}$ pada campuran AC-WC, dan 1241,9 kg berbanding $1094 \mathrm{~kg}$ pada campuran HRS-WC. Hasil uji ketahanan terhadap deformasi menunjukan campuran beraspal dengan asbuton murni lebih tahan terhadap deformasi alur yang ditunjukan dengan nilai stabilitas dinamis yang lebih tinggi yaitu 4200 berbanding 492 lintasan/mm pada campuran AC-WC, dan 2739 berbanding 325 lintasan/mm pada campuran HRS-WC. Nilai modulus resilien campuran dengan asbuton murni mempunyai nilai yang yang lebih tinggi pada temperatur $25^{\circ} \mathrm{C}$ dan setara pada temperatur $35^{\circ} \mathrm{C}$ dan $45^{\circ} \mathrm{C}$. Campuran AC-WC dan HRS-WC dengan asbuton murni mempunyai ketahanan terhadap retak lelah pada regangan uji $150 \mu$ s yang relatif sama dengan campuran aspal minyak, tetapi pada regangan uji yang lebih besar, mempunyai ketahanan terhadap retak lelah yang lebih jelek, khususnya untuk $A C$-WC.
\end{abstract}

Kata kunci: Asbuton, ekstraksi penuh, modulus resilien, retak lelah, stabilitas 


\section{Pendahuluan}

\begin{abstract}
Asbuton
Lebih dari $90 \%$ dari seluruh panjang jalan yang ada di Indonesia menggunakan teknologi perkerasan lentur atau perkerasan beraspal. Untuk memenuhi kebutuhan pembangunan dan pemeliharaan perkerasan beraspal setiap tahun harus import aspal, padahal Indonesia memiliki aspal alam yang depositnya sangat melimpah (Nono, 2015). Kebutuhan aspal nasional Indonesia sekitar 1,2 juta ton pertahun. Berdasarkan kebutuhan tersebut, baru 0,6 juta ton saja yang dapat dipenuhi oleh PT. Pertamina sedangkan sisanya dipenuhi melalui import (Annas et al., 2013). Sementara ketersediaan aspal minyak semakin terbatas dan harga yang cenderung naik terus seiring dengan harga pasar minyak mentah dunia. Untuk menjawab kendala di atas, maka salah satu alternatif yang menjanjikan adalah penggunaan aspal batu buton (asbuton) yaitu sebagai bahan subsitusi aspal minyak. Pemanfaatan asbuton diharapkan dapat mengurangi angka impor aspal minyak sekaligus dapat memanfaatkan kekayaan dalam negeri yang melimpah. Selain itu dengan dikembangkannya aspal lokal ini dapat membuka lapangan kerja lebih luas yang dapat menyerap banyak tenaga kerja (Darma \& Andaka, 2016).
\end{abstract}

Asbuton merupakan aspal alam yang berada di Indonesia, yaitu di Pulau Buton, Provinsi Sulawesi Tenggara. Asbuton pada umumnya berbentuk padat yang terbentuk secara alami akibat proses geologi. Dalam asbuton ini aspal dan mineral sudah bercampur menjadi satu kesatuan dengan kandungan aspal (bitumen) sekitar 15-30\% dan mineral 70-85\% (Sidiq et al., 2013). Proses terbentuknya asbuton berasal dari minyak bumi yang terdorong muncul ke permukaan menyusup di antara batuan yang porous. Diperkirakan deposit asbuton adalah sekitar 677.247 juta ton (Kurniaji, 2010). Cadangan deposit asbuton yang besar tersebut belum dimanfaatkan secara maksimal untuk pembangunan, khususnya jalan baik dalam bentuk asbuton butir maupun asbuton cair (Nuryanto, 2009). Terdapat dua jenis unsur utama dalam asbuton, yaitu aspal (bitumen) dan mineral. Pemanfaatan unsur ini dalam pekerjaan pengaspalan akan mempengaruhi kinerja perkerasan aspal yang direncanakan. Menurut Nugraha, et al (2014) jenis asbuton yang telah diproduksi secara fabrikasi dan manual terdiri dari asbuton butir, asbuton pra-campur (semi ekstraksi), dan asbuton ekstraksi penuh.

Asbuton butir dari daerah Kabungka dikenal dengan istilah Buton Granular Asphalt (BGA) mempunyai ukuran butir maksimum 1,16 $\mathrm{mm}$ dan penetrasi 5 dmm dengan kadar aspal sekitar $20 \%$. Sementara asbuton butir dari Lawele dikenal dengan istilah Lawele Granular Asphalt (LGA), mempunyai ukuran butir maksimum 9,4 mm dengan penetrasi sekitar $50 \mathrm{dmm}$ dan kadar aspal sekitar 30\% (Kurniaji, 2010). Pada campuran beraspal, asbuton dapat digunakan sebagai bahan tambah (additive) atau sebagai bahan substitusi aspal minyak. Sebagai bahan tambah, penggunaan asbuton dimaksudkan untuk meningkatkan mutu aspal minyak atau campuran aspal minyak. Sedangkan sebagai bahan substitusi, penggunaan asbuton dimaksudkan untuk menggantikan fungsi aspal minyak baik sebagian ataupun seluruhnya. Fungsi asbuton juga dapat berperan ganda yaitu sebagai bahan tambah dan sekaligus sebagai bahan substitusi aspal minyak.

\section{Asbuton sebagai bahan tambah (additive)}

Pemanfaatan asbuton butir sebagai bahan tambah pada campuran beraspal mempengaruhi mutu campuran. Asbuton butir adalah hasil pengolahan dari asbuton berbentuk padat yang dipecah dengan alat pemecah batu (crusher) atau alat pemecah lainnya yang sesuai sehingga memiliki ukuran butir tertentu (Setiawan, 2011). Penambahan Asbuton butir pada campuran AC-BC memberikan pengaruh positif yaitu peningkatan pada nilai stabilitas, fleksibilitas, dan durabilitas campuran (Setiawan \& Rahman, 2011).

Pemanfaatan asbuton sebagai bahan penstabil (stabilizer) dan bahan tambah pada campuran SMA (Stone Matrix Asphalt) menunjukkan kinerja yang lebih baik dibandingkan dengan SMA dengan penstabil (stabilizer) serat selulosa dan aspal minyak Pen 60 (Suaryana, 2016). Selain itu pemanfaatan asbuton dengan semi ekstraksi juga dilakukan sebagai bahan campuran SMA yang dicampur dengan bahan pengikat aspal keras penetrasi 60, dengan hasil ketahanan alur dan modululus campuran yang meningkat, serta memperbaiki masalah pengaliran aspal (drain down) dan flushing (Affandi, 2010).

\section{Asbuton sebagai bahan pengganti aspal}

Proses ekstraksi asbuton merupakan proses pemisahan aspal dari mineral asbuton. Pemanfaatan asbuton diupayakan melalui teknologi ekstraksi sehingga aspal dari asbuton pada campuran beraspal akan bekerja efektif dan pemanfaatan bahan asbuton menjadi efisien (Affandi, 2008). Untuk memperoleh bitumen asbuton dengan cara ektraksi penuh telah dicoba digunakan beberapa pelarut seperti Trichlor Ethyline (TCE), premium, benzene, kerosin, 
naphta, toluene, spiritus, bensin, dan minyak tanah atau pelarut lainnya seperti yang telah dilakukan oleh beberapa perusahaan misalnya Alberta, PT. Timah, PT. Buton Asphalt Indonesia, dan PT. Wijaya Karya. Hal yang menjadi kendala, hasil ekstraksi tidak begitu menggembirakan terutama dari segi karakteristik bitumen (asbuton murni) yang dihasilkan serta biaya operasional yang terlalu tinggi, sehingga harga jual asbuton murni tidak kompetitif dengan harga aspal minyak (Kurniaji, 2014). Beberapa hal yang dapat menjadi acuan terhadap baik tidaknya kinerja atau kualitas aspal dalam campuran diantaranya adalah ketahanan terhadap temperatur, nilai modulus resilen, ketahanan deformasi, dan ketahanan retak.

\section{Kepekaan aspal terhadap temperatur}

Aspal merupakan material yang pada temperatur ruang berbentuk padat sampai agak padat, dan bersifat termoplastis. Ketika dipanaskan, sebagian besar interaksi fisika-kimia di dalam aspal tersebut melemah atau bahkan hilang sama sekali. Kondisi ini membuat bagian-bagian tunggal dari rantai molekulnya menjadi lebih mudah bergerak, sehingga terjadi penurunan kekakuan dan kekentalan (viskositas). Perubahan sifat viskoelastisitas aspal akibat perubahan temperatur dinyatakan dengan nilai indeks penetrasi aspal (IP) (Indriyati, 2017).

Nilai IP aspal berkisar antara -3 sampai +7 , aspal dengan nilai IP yang tinggi lebih tidak peka terhadap perubahan temperatur dan sebaliknya. Selain itu, nilai IP aspal dapat juga digunakan untuk memprediksi kinerja campuran beraspal, aspal dengan IP yang tinggi akan menghasilkan campuran beraspal yang memiliki modulus kekakuan dan ketahanan terhadap deformasi yang tinggi (Suaryana et al., 2014). Nilai IP aspal dapat dihitung dengan menggunakan rumusan yang diturunkan oleh Pfeiffer (1936) dalam Shell (2015) dan dikembangkan lebih lanjut oleh Heukelom (Shell, 2015), yaitu:

$\mathrm{IP}=\frac{20(1-25 \mathrm{~A})}{(1+50 \mathrm{~A})}$

dimana nilai A diperoleh dari hasil pengujian penetrasi pada dua jenis temperatur pengujian, T1 dan T2 dengan persamaan sebagai berikut:

$A=\frac{\log \mathrm{T} 1-\log 800}{\text { T1-Titik Lembek }}$

\section{Modulus Resilien}

Kondisi mayoritas campuran beraspal jalan tidak bersifat elastis karena mengalami deformasi permanen pada tiap pengulangan pembebanan. Namun demikian jika beban tersebut relatif kecil dibandingkan dengan kekuatan material dan mengalami pengulangan pembebanan yang tinggi, sehingga deformasi yang terjadi pada setiap pengulangan pembebanan adalah hampir dapat kembali sempurna (nearly complete recoverable) dan proporsional terhadap pembebanan, maka material tersebut dianggap material yang elastis (Huang, 2004). Pengujian modulus resilien dapat dilakukan dengan uji tarik langsung (indirect tensile test). Faktor utama yang perlu diperhatikan pada pengujian modulus resilien campuran beraspal adalah temperatur dan frekwensi pembebanan. Dua faktor ini memberikan pengaruh yang besar pada nilai modulus resilien.

\section{Ketahanan deformasi}

Menurut NCHRP (2004) deformasi permanen atau rutting adalah penurunan permukaan pada jejak roda yang disebabkan oleh deformasi plastis pada setiap atau seluruh lapisan perkerasan dan subgrade. Deformasi plastis umumnya disebabkan oleh idensifikasi atau kompresi satu dimensi atau konsolidasi, dan pergerakan arah lateral atau plastic flow dari lapis perkerasan (campuran beraspal, agregat base/sub base dan tanah dasar). Pengujian terhadap ketahanan deformasi alur dilakukan dengan alat WTM (Wheel Tracking Machine). Semakin tinggi nilai kedalaman alur, deformasi awal, dan kecepatan deformasi menunjukan ketahanan campuran yang rendah. Untuk nilai stabilitas dinamis, menyatakan bahwa semakin tinggi nilai tersebut maka ketahanan terhadap deformasi adalah lebih baik.

\section{Ketahanan retak}

Kelelahan merupakan suatu fenomena timbulnya retak akibat beban berulang yang terjadi karena pengulangan tegangan atau regangan yang batasnya masih di bawah batas kekuatan material (Pradani et al., 2011). Ketahanan retak campuran aspal dapat diketahui dengan uji kelelahan (fatique). Pengujian kelelahan dilakukan untuk mendapatkan hubungan antara tegangan dan regangan dengan umur kelelahan. Pengujian kelelahan dapat dilakukan dengan beberapa metoda dan menggunakan berbagai bentuk dan ukuran benda uji.

\section{Keterbaruan penelitian}

Beberapa hal yang menjadi keterbaruan pada penelitian ini adalah sebagai berikut:

\section{Penggunaan pelarut (solvent)}

Penggunaan jenis pelarut yang berbeda pada proses ektraksi asbuton akan diperoleh hasil 
kinerja aspal hasil ekstraksi yang berbeda pula. Pada penelitian oleh Kurniaji (2014) jenis bahan pelarut berbasis bahan organik yaitu terpentin yang ditambah dengan surfactan (surface active agent). Variasi penambahan bahan surfactan ke dalam terpentin akan menghasilkan bitumen asbuton dengan persentase yang bervariasi juga. Sementara pada penelitian oleh Affandi (2006) jenis pelarut yang digunakan adalah Trichlor Ethyline (TCE) dengan proses destilasi. Penggunaan pelarut jenis kerosin juga ada yang diterapkan untuk ekstraksi asbuton (Sidiq et al., 2013). Pada penelitian ini metode ekstraksi yang digunakan adalah teknik two stages counter current extraction (ekstraksi arah berlawanan 2 tahap). Pada pelaksanaan counter current extraction, fase cair pengekstraksi dialirkan dengan arah yang berlawanan dengan larutan yang mengandung zat yang akan diekstraksi, dengan menggunakan larutan solvent berbahan hidrokarbon.

\section{Skala produksi}

Penelitian sebelumnya terkait ektraksi asbuton telah dilakukan oleh banyak peneliti, seperti Affandi, Kurniaji, dan Sidiq. Hal yang menjadi pembeda terhadap penelitian sebelumnya yaitu bahwa penelitian tersebut masih dalam tahap skala laboratorium. Sementara pada penelitian ini, tahap pelaksanaan sudah mencapai tahap skala pabrik yang dilakukan oleh PT. Wika Bitumen pada tahun 2017.

\section{Fungsi asbuton}

Hal yang menjadi pembeda dari penelitian lain sebelumnya yaitu fungsi asbuton pada campuran ini adalah sebagai bahan pengganti aspal minyak beraspal. Hal tersebut membuat campuran dengan asbuton pada penelitian ini juga diterapkan pada campuran HRS-WC tidak hanya pada campuran AC-WC.

Tujuan dari penelitian ini adalah untuk mengetahui kinerja campuran beraspal panas AC-WC dan HRS-WC dengan menggunakan bitumen hasil ekstraksi penuh asbuton (subsitusi aspal minyak Pen 60 dengan bitumen asbuton seluruhnya) yang diproduksi oleh PT. Wika Bitumen pada akhir tahun 2017. Sebagai pembanding digunakan campuran beraspal panas AC-WC dan HRS-WC yang menggunakan aspal minyak penetrasi 60 (Pen $60)$.

\section{Metode}

Penelitian terhadap kinerja campuran beraspal asbuton hasil ekstraksi penuh ini menggunakan metode eksperimen dan dianalisa dengan membandingkan kinerjanya dengan campuran beraspal konvensional yang menggunakan aspal minyak Pen 60. Bahan aspal minyak yang digunakan pada penelitian adalah aspal minyak Pen 60 yang diproduksi oleh PT. Pertamina (Persero). Untuk asbuton, yang digunakan berupa asbuton murni yang diproduksi oleh PT. Wijaya Karya Bitumen, sebagai hasil ekstraksi penuh secara pabrikasi terhadap asbuton butir dari Lawele.

Tahapan penelitian meliputi studi literatur, pengujian karakteristik bahan, perancangan campuran (Marshall), pengujian karakteristik campuran yang meliputi pengujian modulus resilien, pengujian ketahanan terhadap alur/deformasi, dan pengujian ketahanan terhadap retak lelah. Campuran beraspal yang digunakan untuk menganalisa kinerja asbuton murni pada penelitian ini adalah campuran AC-WC dan HRSWC gradasi senggang. Spesifikasi campuran beraspal panas yang digunakan sebagai acuan adalah SNI 8198:2015. Untuk perancangan campuran beraspal, digunakan metoda Marshall yang mengacu pada SNI 2489:2014.

Pengujian modulus resilien di laboratorium sesuai dengan ASTM D4123-82; menggunakan pola pembebanan cyclic loading dengan konfigurasi beban berupa diametral loading (American Society for Testing and Material, ASTM, 1995). Pengujian ini dilaksanakan dengan frekwensi $0,33 \mathrm{~Hz}$ (pulse repetition period $3000 \mathrm{~ms}$ ), serta dengan variasi temperatur yaitu $25^{\circ} \mathrm{C}, 35^{\circ} \mathrm{C}$, dan $45^{\circ} \mathrm{C}$. Beban puncak yang digunakan adalah $1500 \mathrm{~N}$. Pengujian dilakukan dengan dua contoh uji (duplo) dengan hasil dirata-rata.

Pengujian ketahanan campuran terhadap deformasi permanen (alur) dilakukan dengan alat WTM (Wheel Tracking Machine) pada temperatur $60^{\circ} \mathrm{C}$ dengan beban sebesar $6,4 \mathrm{~kg} / \mathrm{cm}^{2}$ yang menggambarkan beban berat dan dilakukan selama 60 menit. Nilai hasil pengujian deformasi akan menunjukan kinerja daya tahan campuran terhadap alur. Pada penelitian ini, pengujian ketahanan campuran terhadap retak lelah (fatigue), dilakukan pada temperatur pengujian sebesar $20^{\circ} \mathrm{C}$. Benda uji dipadatkan dengan alat pemadat WTM, dengan tebal contoh yang disesuaikan untuk keperluan pengujian retak lelah. Benda uji berupa balok dengan ukuran $6 \times 5 \times 48 \mathrm{~cm}^{3}$ diberi beban berulang dengan regangan yang tetap, sampai balok tersebut mengalami keruntuhan yang didefinisikan saat modulusnya telah mencapai $50 \%$ dari modulus awalnya.

Pengujian laboratorium terhadap ketahanan deformasi/alur menggunakan alat WTM, dengan 
metoda pengujian mengacu pada Japan Road Assosiation, 1980. Sementara untuk pengujian ketahanan terhadap retak lelah, alat yang dipakai adalah mesin uji kelelahan Beam Fatigue Apparatus (BFA). Alat ini mengakomodasi pengujian kelelahan dengan kontrol regangan (strain). Pelaksanaan pengujian mengacu pada AASHTO T 321-14 (AASHTO, 2014).

\section{Hasil dan Pembahasan}

\section{Karakteristik aspal}

Hasil pengujian karakteristik dari aspal minyak Pen 60 dan asbuton Lawele tersebut dibandingkan dengan spesifikasi SNI 8198:2015, seperti diperlihatkan pada Tabel 1. Aspal hasil ekstraksi asbuton (asbuton murni) mempunyai nilai penetrasi yang relatif rendah dengan nilai penetrasi $40 \mathrm{dmm}$. Tingkat kemurnian asbuton setara dengan aspal minyak, yaitu di atas $99 \%$ (kelarutan dalam $\mathrm{C}_{2} \mathrm{HCl}_{3}$ ). Titik lembek di atas aspal minyak Pen
60, namun masih di bawah asbuton yang diproses (asbuton semi ekstraksi atau asbuton pracampur).

Hasil pengujian karakteristik bitumen hasil ekstraksi asbuton yang ditampilkan pada Tabel 1 menunjukkan bahwa sebagian besar sifat fisik asbuton murni yang digunakan memenuhi spesifikasi SNI 8198:2015 untuk aspal Pen 60, kecuali nilai penetrasi yang tidak memenuhi, yaitu hanya $40 \mathrm{dmm}$. Meskipun demikian asbuton mempunyai keunggulan dari segi nilai titik lembek yang lebih tinggi dibanding aspal minyak Pen 60.

Hasil analisa kepekaan aspal terhadap temperatur berdasarkan rumus IP sesuai persamaan (1), diperoleh IP bitumen asbuton murni sebesar -1,02 Nilai tersebut relatif sama dibandingkan dengan IP aspal minyak Pen 60, yaitu -0,99. Hasil tersebut menunjukkan asbuton murni mempunyai kepekaan terhadap temperatur yang relatif sama dengan aspal minyak Pen 60.

Tabel 1. Hasil pengujian karakteriktik bitumen aspal minyak Pen 60 dan asbuton murni

\begin{tabular}{|c|c|c|c|c|c|c|c|}
\hline \multirow[b]{2}{*}{ No } & \multirow{2}{*}{ Jenis pengujian } & \multirow[b]{2}{*}{ Standar uji } & \multicolumn{2}{|c|}{ Hasil uji } & \multicolumn{2}{|c|}{$\begin{array}{c}\text { Spesifikasi SNI } \\
\text { 8198:2015 }\end{array}$} & \multirow{2}{*}{ Unit } \\
\hline & & & Pen 60 & $\begin{array}{l}\text { Asbuton } \\
\text { murni }\end{array}$ & Pen 60 & $\begin{array}{l}\text { Asbuton di } \\
\text { proses }\end{array}$ & \\
\hline 1 & Penetrasi pada $25^{\circ} \mathrm{C}$ & SNI 2456:2011 & 63,00 & 40,00 & $60-70$ & $\min .40$ & $\mathrm{dmm}$ \\
\hline \multirow[t]{3}{*}{2} & $\begin{array}{l}\text { Kekentalan pada } \\
\text { temperatur }\end{array}$ & & & & & & \\
\hline & $60^{\circ} \mathrm{C}$ (poise) & SNI 03-6440-2000 & 2093,00 & 4921,00 & $\min .1600$ & $\min .3200$ & Poise \\
\hline & $135^{\circ} \mathrm{C}(\mathrm{cSt})$ & ASTM D2170-10 & 353,00 & 517,00 & maks.3000 & maks.3000 & $\mathrm{cSt}$ \\
\hline 3 & Titik lembek & SNI 2434:2011 & 48,70 & 52,80 & $\min .48$ & $\min .53$ & ${ }^{\circ} \mathrm{C}$ \\
\hline 4 & Daktilitas pada $25^{\circ} \mathrm{C}$ & SNI 2432:2011 & $>140,00$ & $>140,00$ & $\min .100$ & $\min .100$ & $\mathrm{Cm}$ \\
\hline 5 & Titik nyala & SNI 2433:2011 & 328,00 & 280,00 & $\min .232$ & $\min .232$ & ${ }^{\circ} \mathrm{C}$ \\
\hline 6 & $\begin{array}{l}\text { Kelarutan dalam } \\
\text { Trichloroethylene }\end{array}$ & SNI 06-2438-1991 & 99,80 & 99,80 & $\min .99$ & $\min .90$ & $\%$ \\
\hline 7 & Berat jenis aspal & SNI 2441:2011 & 1,03 & 1,04 & $\min .1,0$ & $\min .1,0$ & \\
\hline \multicolumn{8}{|c|}{ Pengujian residu hasil TFOT pada $165^{\circ} \mathrm{C}, 5$ jam } \\
\hline 8 & Berat yang hilang & SNI 06-2440-1991 & 0,02 & 0,15 & maks. 0,8 & maks. 0,8 & $\%$ \\
\hline 9 & Penetrasi pada $25^{\circ} \mathrm{C}$ & SNI 2456:2011 & 82,10 & 80,00 & $\min .54$ & $\min .54$ & $\%$ \\
\hline 10 & Daktilitas pada pada $25^{\circ} \mathrm{C}$ & SNI 2432:2011 & $>140,00$ & $>140,00$ & $\min .100$ & $\min .50$ & $\mathrm{Cm}$ \\
\hline
\end{tabular}

Tabel 2. Karakteristik campuran beraspal AC-WC dengan aspal minyak Pen 60 dan asbuton murni

\begin{tabular}{|c|c|c|c|c|c|c|}
\hline No & Sifat-sifat campuran & Standar uji & $\begin{array}{c}\text { AC-WC } \\
\text { dengan aspal } \\
\text { Pen } 60\end{array}$ & $\begin{array}{c}\text { AC-WC } \\
\text { dengan } \\
\text { asbuton murni }\end{array}$ & $\begin{array}{c}\text { Spesifikasi SNI } \\
\text { 8198:2015 }\end{array}$ & Unit \\
\hline & Kadar aspal optimum (\%) & & 5,80 & 5,80 & & $\%$ \\
\hline 21 & Rasio abu terhadap aspal & AASHTO M323 & 1,10 & 1,10 & $0,6-1,2$ & \\
\hline & $\begin{array}{l}\text { Rongga dalam campuran } \\
\text { (VIM) }\end{array}$ & AASHTO M323 & 3,80 & 3,00 & $3,0-5,0$ & $\%$ \\
\hline & $\begin{array}{l}\text { Rongga dalam mineral } \\
\text { agregat (VMA) }\end{array}$ & AASHTO M323 & 15,80 & 15,00 & Min. 15 & $\%$ \\
\hline & Rongga terisi aspal (VFB) & AASHTO M323 & 76,00 & 80,00 & Min. 65 & $\%$ \\
\hline & Stabilitas Marshall & ASTM D6927-06 & 1100,00 & 1871,00 & Min. 800 & $\mathrm{Kg}$ \\
\hline & Pelelehan & ASTM D6927-06 & 2,08 & 2,04 & $2-4$ & $\mathrm{~mm}$ \\
\hline & Stabilitas sisa $(\%)$ & & 90,40 & 90,10 & Min. 90 & $\%$ \\
\hline
\end{tabular}




\section{Rancangan campuran beraspal AC-WC}

Perancangan campuran beraspal AC-WC menggunakan metoda Marshall (Badan Standarisasi Nasional, 2014) dengan hasil seperti diperlihatkan pada Tabel 2. Berdasarkan hasil rancangan tersebut terlihat bahwa kedua jenis campuran masih memenuhi persyaratan yang ditetapkan dalam SNI 8198:2015 untuk campuran beraspal laston AC-WC. Nilai stabilitas campuran dengan asbuton murni jauh lebih tinggi dari nilai stabilitas campuran dengan aspal minyak Pen 60, sementara nilai pelelehan kurang lebih sama. Hal ini mengindikasikan campuran aspal dengan asbuton murni mempunyai kekakuan yang lebih tinggi.

\section{Rancangan campuran beraspal HRS-WC}

Sementara untuk perbandingan karakteristik campuran beraspal HRS-WC dengan menggunakan aspal minyak Pen 60 dan asbuton murni adalah sesuai dengan Tabel 3. Berdasarkan hasil pengujian terhadap penggunaan asbuton murni pada campuran beraspal HRS-WC menunjukkan bahwa karakteristik campuran dengan asbuton murni memenuhi syarat spesifikasi dan mempunyai sifat yang setara dengan campuran dengan aspal minyak. Nilai stabilitas campuran dengan asbuton murni pada campuran HRS-WC lebih tinggi dari nilai stabilitas campuran dengan aspal minyak Pen 60. Nilai stabilitas sisa HRS-WC dengan asbuton murni lebih tinggi yang menunjukkan campuran lebih tahan terhadap air.

\section{Modulus resilien}

Berdasarkan Gambar 1, terlihat bahwa nilai modulus resilien akan turun dengan meningkatnya temperatur pengujian. Nilai modulus resilien campuran beraspal baik AC-WC maupun HRSWC dengan asbuton murni lebih besar dibandingkan dengan campuran dengan aspal minyak Pen 60 , pada temperatur $25^{\circ} \mathrm{C}$.

Namun pada temperatur $35^{\circ} \mathrm{C}$ dan $45^{\circ} \mathrm{C}$, nilai modulus resilien campuran beraspal dengan asbuton murni tidak berbeda jauh dengan nilai modulus resilien pada campuran beraspal dengan aspal Pen 60.

\section{Ketahanan terhadap deformasi}

Hasil pengujian deformasi antara campuran beraspal dengan aspal minyak Pen 60 dan asbuton murni pada campuran AC-WC dan HRS-WC

Tabel 3. Krakteristik campuran beraspal HRS-WC dengan aspal minyak Pen 60 dan asbuton murni

\begin{tabular}{|c|c|c|c|c|c|}
\hline Sifat-sifat campuran & Standar uji & $\begin{array}{c}\text { HRS-WC } \\
\text { dengan aspal } \\
\text { pen } 60\end{array}$ & $\begin{array}{c}\text { HRS-WC } \\
\text { dengan } \\
\text { asbuton murni }\end{array}$ & $\begin{array}{c}\text { Spesifikasi } \\
\text { umum bina } \\
\text { marga } 2010 \\
\end{array}$ & Unit \\
\hline 1 Kadar aspal optimum (\%) & & 7,30 & 7,30 & & $\%$ \\
\hline $\begin{array}{l}2 \text { Rongga dalam campuran } \\
\text { (VIM) }\end{array}$ & AASHTO M323 & 5,10 & 5,20 & $4,0-6,0$ & $\%$ \\
\hline $\begin{array}{l}3 \text { Rongga dalam mineral } \\
\text { agregat (VMA) }\end{array}$ & AASHTO M323 & 19,50 & 19,46 & Min. 18 & $\%$ \\
\hline 4 Rongga terisi aspal (VFB) & AASHTO M323 & 73,90 & 80,46 & Min. 68 & $\%$ \\
\hline 5 Stabilitas Marshall & ASTM D6927-06 & 1094,00 & 1241,90 & Min. 800 & $\mathrm{Kg}$ \\
\hline 6 Pelelehan & ASTM D6927-06 & 3,20 & 3,30 & Min. 3 & $\mathrm{~mm}$ \\
\hline 7 Stabilitas sisa $(\%)$ & & 90,50 & 96,90 & Min. 90 & $\%$ \\
\hline
\end{tabular}

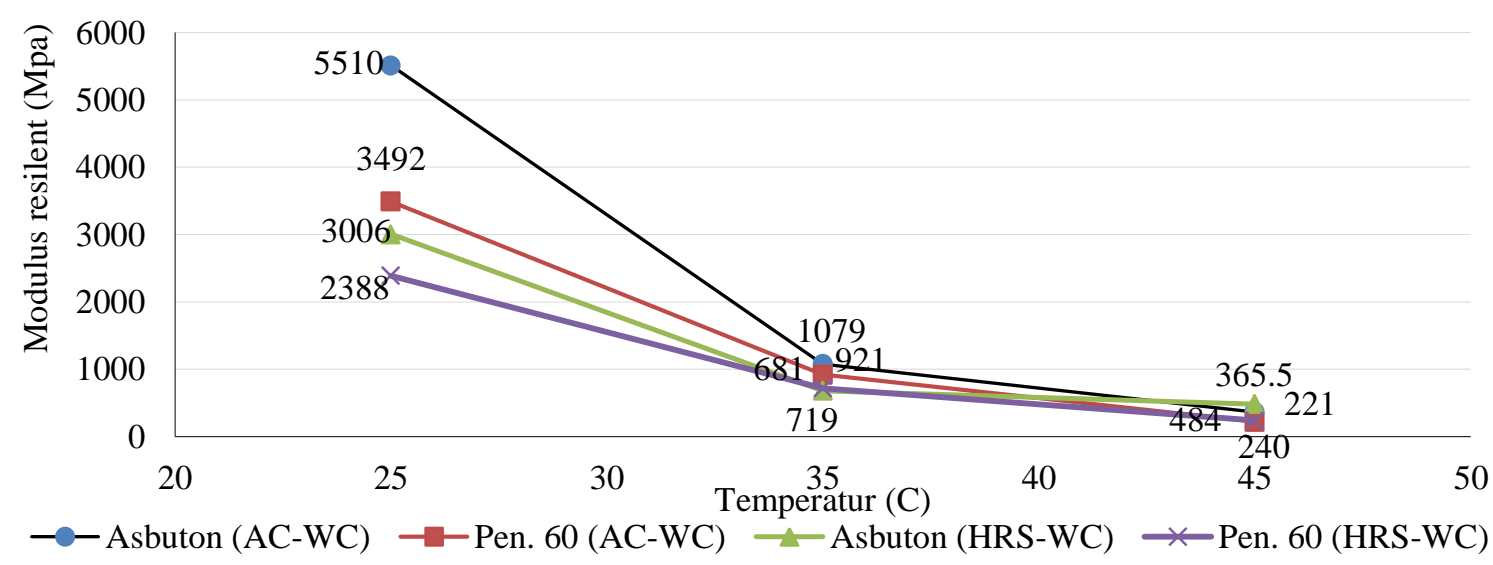

Gambar 1. Hubungan nilai modulus resilien dengan temperatur 
adalah sesuai dengan Tabel 4. Berdasarkan Tabel 4, terlihat campuran beraspal menggunakan asbuton murni sebagai bahan pengikat mempunyai ketahanan terhadap deformasi permanen atau alur yang lebih baik untuk AC-WC maupun HRS-WC. Hal ini ditunjukan dengan nilai kedalaman alur, deformasi awal, dan kecepatan deformasi dari campuran dengan asbuton murni yang lebih rendah dibandingkan dengan campuran dengan Pen 60. Selain itu nilai stabilitas dinamis campuran asbuton murni jauh lebih tinggi dibandingkan dengan campuran dengan Pen 60.

Tabel 4. Pengujian stabilitas dinamis campuran

\begin{tabular}{lrrrr}
\hline \multirow{2}{*}{ Uraian } & \multicolumn{2}{c}{ AC-WC } & \multicolumn{2}{c}{ HRS-WC } \\
\cline { 2 - 5 } & $\begin{array}{c}\text { Pen } \\
\text { 60/70 }\end{array}$ & $\begin{array}{c}\text { Asbuton } \\
\text { Murni }\end{array}$ & $\begin{array}{c}\text { Pen } \\
\text { 60/70 }\end{array}$ & $\begin{array}{c}\text { Asbuton } \\
\text { Murni }\end{array}$ \\
\hline $\begin{array}{l}\text { Kedalaman } \\
\text { alur (mm) }\end{array}$ & 7,81 & 2,66 & 7,98 & 2,22 \\
\hline $\begin{array}{l}\text { Deformasi } \\
\text { awal (mm) }\end{array}$ & 2,65 & 2,06 & 2,01 & 1,33 \\
\hline $\begin{array}{l}\text { Kecepatan } \\
\text { deformasi } \\
\text { (mm/menit) }\end{array}$ & 0,086 & 0,01 & 0,1293 & 0,0153 \\
\hline $\begin{array}{l}\text { Stabilitas } \\
\text { dinamis } \\
\text { (lintasan/mm) }\end{array}$ & 492 & 4200 & 325 & 2739 \\
\hline
\end{tabular}

\section{Ketahanan terhadap retak}

Pengujian AC-WC dilakukan dengan kontrol regangan (tensile strain), yaitu pada nilai regangan sebesar $400 \mu \varepsilon, 350 \mu \varepsilon, 300 \mu \varepsilon$, dan $250 \mu \varepsilon$. Hasil interpolasi pengujian campuran beraspal AC-WC diperlihatkan pada Gambar 2.

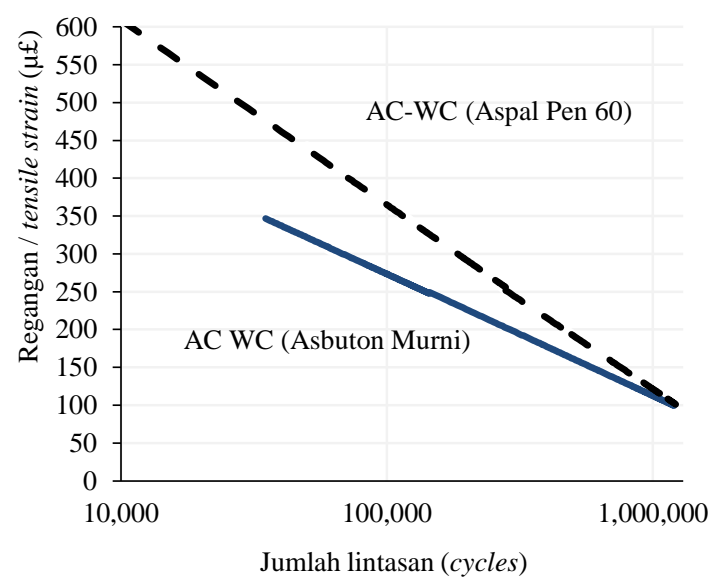

Gambar 2. Perbandingan uji fatigue antara campuran beraspal AC-WC dengan aspal pen 60 dengan asbuton murni

Berdasarkan hasil pengujian, menunjukkan campuran beraspal AC-WC dengan asbuton murni pada regangan uji yang besar (di atas nilai regangan $250 \mu \varepsilon$ ) mempunyai ketahanan terhadap retak lebih kecil dibandingkan dengan campuran beraspal dengan aspal minyak. Hasil ini menunjukkan kinerja yang lebih buruk jika dilihat dari aspek ketahanan terhadap retak, khususnya pada regangan uji yang besar. Apabila kurva diinterpolasi sampai dengan nilai regangan uji 150 $\mu \varepsilon$ maka ketahanan campuran dengan asbuton murni hampir setara dengan campuran dengan aspal minyak.

Pengujian HRS-WC dilakukan dengan kontrol regangan (tensile strain), yaitu pada nilai 600, 500 dan $400 \mu \varepsilon$. Hasil interpolasi pengujian campuran beraspal HRS-WC diperlihatkan Gambar 3.

Berdasarkan hasil pengujian terlihat bahwa campuran beraspal HRS-WC dengan asbuton murni pada regangan 600 sampai 500 dan $400 \mu \varepsilon$ mempunyai ketahanan retak yang relatif sama dengan HRS WC yang menggunakan aspal minyak Pen 60. Apabila kurva diinterpolasi sampai dengan nilai regangan uji $150 \mu \varepsilon$ maka ketahanan campuran dengan asbuton murni hampir setara dengan campuran dengan aspal minyak.

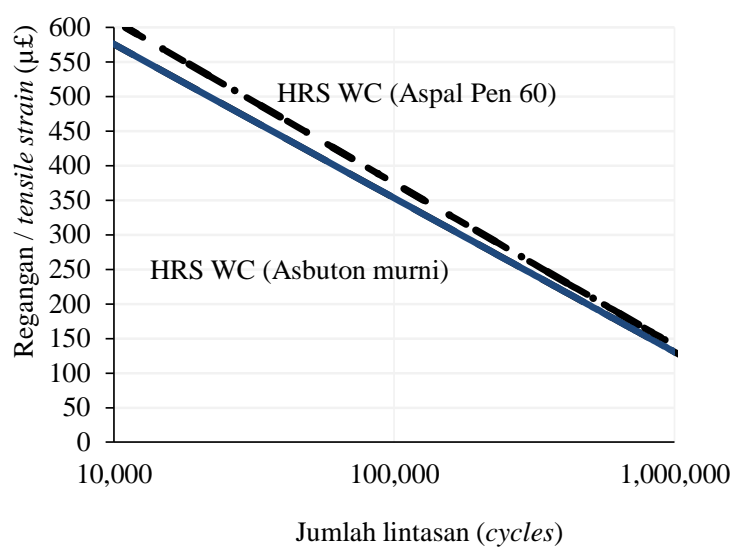

Gambar 3. Perbandingan uji fatigue antara campuran beraspal HRS-WC dengan aspal pen 60 dengan asbuton murni

\section{Pembahasan}

Berdasarkan data hasil uji karakteristik bitumen, menunjukkan asbuton murni yang diperoleh dari hasil ekstraksi, tidak memenuhi persyaratan spesifikasi berdasarkan kelas penetrasi. Nilai penetrasinya lebih rendah dari persyaratan aspal minyak Pen 60, namun mempunyai titik lembek yang lebih tinggi. Disisi lain, apabila kinerja aspal dinilai berdasarkan nilai indeks penetrasi (IP), maka nilai IP asbuton murni tidak jauh berbeda dengan nilai IP dari campuran aspal minyak yaitu 0,99 dibandingkan dengan $-1,02$, sehingga dapat dikatakan bahwa kepekaan terhadap temperatur relatif sama. Berdasarkan hasil pengujian Marshall, diperoleh bahwa karakteristik campuran 
beraspal dengan ekstraksi asbuton murni baik pada campuran AC-WC maupun HRS-WC lebih baik dibandingkan karakteristik campuran beraspal dengan aspal minyak Pen 60 ditinjau dari nilai stabilitas Marshall yang lebih tinggi.

Hasil uji ketahanan terhadap deformasi permanen atau alur dengan alat WTM menunjukkan campuran beraspal dengan asbuton murni baik pada campuran AC-WC maupun HRS-WC lebih tahan terhadap alur dibandingkan aspal minyak Pen 60 yang ditunjukkan dengan nilai stabilitas dinamis yang lebih tinggi dibandingkan aspal minyak Pen 60 yaitu, 4200 lintasan $/ \mathrm{mm}$ berbanding dengan 492 lintasan $/ \mathrm{mm}$ pada campuran beraspal AC-WC, dan 2739 lintasan/mm berbanding 325 lintasan/mm pada HRS-WC.

Nilai modulus resilien campuran beraspal dengan asbuton murni mempunyai nilai yang yang lebih tinggi pada temperatur $25^{\circ} \mathrm{C}$ dan setara pada temperatur $35^{\circ} \mathrm{C}$ dan $45^{\circ} \mathrm{C}$. Mengacu pada Manual Disain Perkerasan (Bina Marga, 2017) temperatur perkerasan yang digunakan sebagai acuan untuk perencanaan adalah Temperatur Perkerasan Tahunan Rata-rata (MAPT) $41^{\circ} \mathrm{C}$, dengan demikian dapat dikatakan bahwa nilai modulus resilien campuran beraspal untuk dua jenis aspal tersebut mempunyai nilai yang sama. Berdasarkan dengan nilai modulus yang sama tersebut maka otomatis koefisien relatif kedua jenis perkerasan tersebut juga sama, yaitu antara 0,35 sampai dengan 0,40 (Bina Marga, 2017).

Berdasarkan hasil pengujian, menunjukkan campuran beraspal AC-WC dengan asbuton murni pada regangan uji di atas $250 \mu \varepsilon$ mempunyai ketahanan terhadap retak yang lebih kecil dibandingkan dengan campuran aspal minyak Pen 60. Sementara untuk campuran beraspal HRS-WC dengan asbuton murni, ketahanan terhadap retak relatif setara bila dibandingkan dengan campuran dengan aspal minyak Pen 60.

Menurut Bina Marga (2017) kinerja retak lelah tersebut tidak merupakan persyaratan untuk jalan dengan tingkat lalu-lintas ringan atau untuk desain dengan beban lalu lintas rencana kurang $10^{5}$ ESA, karena kinerja retak lelah (fatigue) bukan merupakan kerusakan yang umum pada jalan dengan lalu lintas ringan.

Mengacu pada Australian Asphalt Pavement Association, 2017 spesifikasi kinerja campuran beraspal yang digunakan salah satunya adalah hasil uji ketahanan terhadap retak lelah pada pengujian temperatur $20^{\circ} \mathrm{C}$ dan frekwensi $10 \mathrm{~Hz}$, jumlah lintasan sebanyak $10^{6}$ tercapai pada nilai minimum regangan (strain) $150 \mu \varepsilon$. Apabila menggunakan spesifikasi tersebut maka kinerja AC-WC dan HRS-WC dengan menggunakan asbuton murni mempunyai kinerja yang sama dengan menggunakan aspal minyak Pen 60.

\section{Kesimpulan}

Berdasarkan hasil analisis dan pembahasan pada penelitian ini, dapat disimpulkan Aspal yang diperoleh dari hasil ekstraksi penuh asbuton tidak masuk spesifikasi untuk aspal keras. Nilai penetrasinya lebih rendah dari persyaratan aspal minyak Pen 60, namun mempunyai keunggulan yaitu dari segi nilai titik lembek yang lebih tinggi.

Hasil uji ketahanan terhadap deformasi menunjukan campuran beraspal dengan asbuton murni lebih tahan terhadap deformasi alur yang ditunjukan dengan nilai stabilitas dinamis yang lebih tinggi dibandingkan dengan campuran beraspal dengan Pen 60. Nilai modulus resilien campuran beraspal dengan asbuton murni mempunyai nilai yang yang lebih tinggi pada temperatur $25^{\circ} \mathrm{C}$ dan setara pada temperatur $35^{\circ} \mathrm{C}$ dan $45^{\circ} \mathrm{C}$.

Campuran beraspal AC-WC dan HRS-WC dengan asbuton murni mempunyai ketahanan terhadap retak lelah pada regangan uji $150 \mu$ s yang relatif sama dengan campuran aspal minyak, tetapi pada regangan uji yang lebih besar, mempunyai ketahanan terhadap retak lelah yang lebih buruk, khususnya untuk AC-WC. Diperlukan pengembangan acuan spesifikasi khusus untuk aspal hasil ektraksi asbuton, karena walaupun aspal hasil ekstraksi asbuton tidak masuk spesifikasi aspal keras namun mempunyai kinerja yang baik pada campuran beraspal.

\section{Ucapan Terima Kasih}

Ucapan terima kasih kami tujukan kepada Pusat Penelitian dan Pengembangan Jalan dan Jembatan (Pusjatan), Badan Penelitian dan Pengembangan, Kementerian Pekerjaan Umum dan Perumahan Rakyat yang telah memfasilitasi pelaksanaan penelitian ini.

\section{Daftar Pustaka}

AASHTO. (2014). Determining the fatigue life of compacted Hot Mix Asphalt (HMA) subjected to repeated flexural bending. standard specifications for transportation materials and methods of sampling and testing part 2B AASHTO T 321-14, Washington, D.C: American Association of State Highway and Transportation Officials. 
Affandi, F. (2006). Hasil pemurnian asbuton Lawele sebagai bahan pada campuran beraspal untuk perkerasan jalan. Jurnal Jalan-Jembatan, 3(23), 6-28.

Affandi, F. (2008). Karakteristik bitumen asbuton butir untuk campuran beraspal panas. Jurnal Jalan-Jembatan, 25(3), 350-368.

Affandi, F. (2010). Pengaruh asbuton semi ekstraksi pada campuran stone mastic asphalt. Jurnal Jalan-Jembatan, 27(1), 1-13.

American Society for Testing and Material (ASTM). (1995). Standard Test Method for Indirect Tension Test for Resilient Modulus of Bituminous Mixtures D4123-82, In ASTM International (Ed.), West Conshohocken.

Annas, L., Sarwono, D., \& Djumari. (2013). Ekstraksi asbuton butir dengan metode asbuton emulsi menggunakan pengelmulsi texapon ditinjau dari konsentrasi air dan waktu ekstraksi. Jurnal Matrik Teknik Sipil, 1(4), 440-445.

Australian Asphalt Pavement Association. (2017). Model specificatio, Australia: National Technology \& Leadership Committee.

Badan Standarisasi Nasional. (2014). Metoda uji stabilitas dan pelelehan campuran beraspal panas dengan menggunakan alat Marshall, SNI 2489:2014, Jakarta.

Bina Marga. (2017). Manual disain perkerasan, Jakarta: Kementerian Pekerjaan Umum dan Perumahan Rakyat.

Darma, R., \& Andaka, G. (2016). Re-ekstrasi aspal buton kabungka dengan menggunakan solven kondensat bensin. Jurnal Inovasi Proses, 1(2), $1-6$.

Huang, Y. (2004). Pavement analysis and design, New Jersey, USA: Prentice Hall.

Indriyati, E. W. (2017). Pengaruh asbuton murni terhadap indeks penetrasi aspal. Jurnal Transportasi, 17(3), 185-192.

Japan Road Assosiation. (1980). Manual design and contraction of asphalt pavement, Japan: Japan Road Assosiation.

Kurniaji. (2010). Kajian ekstraksi asbuton, Bandung: Pusat Litbang Jalan dan Jembatan.

Kurniaji. (2014). Ekstraksi asbuton dengan pelarut berbasis bahan organik dan media air. Jurnal Jalan-Jembatan, 31(1), 12-23.

NCHRP. (2004). Guide for mechanistic-empirical design, Part 3 Chapter 3 Flexibe Design, Washington, D.C: National Research Council.

Nono. (2015). Pengembangan teknologi aditif untuk campuran beraspal yang menggunakan RAP dan asbuton, Bandung: Pusat Litbang Jalan dan Jembatan.

Nugraha, E., Sarwono, D., \& Setyawan, A. (2014). Kinerja properti semarbut aspal tipe i (penambahan ekstraksi asbuton emulsi sebagai modifikasi bitumen). E-Jurnal Matrik Teknik Sipil, 2(1), 9-15.

Nuryanto, A. (2009). Aspal buton (asbuton) sebagai bahan bakar roket padat. Jurnal Teknologi Dirgantara, 7(1), 36-45.

Pradani, N., Subagio, B., \& Rahman, H. (2011). Kinerja kelelahan campuran beton aspal lapis aus menggunakan material hasil daur ulang dan polimer styrene-butadiene-styrene. Transportasi, 11(3), 163-172.

Setiawan, A. (2011). Studi penggunaan asbuton butir terhadap karakteristik marshall asphatic concrete wearing course asbuton campuran hangat (AC - WC - ASB - H). Jurnal Smartek, 9(1), 1127.

Setiawan, A., \& Rahman, R. (2011). Studi penggunaan asbuton butir pada campuran beton aspal binder course (Ac-Bc). Jurnal Rekayasa dan Manajemen Transportasi, 1(2), 99-118.

Shell. (2015). the shell bitumen handbook (Sixth Edit), UK: Shell.

Sidiq, M., Rachmadani, S., Altway, A., \& Nurkhamidah, S. (2013). Studi proses pemisahan bitumen dari asbuton dengan proses hot water menggunakan bahan pelarut kerosin dan larutan surfaktan. Jurnal Teknik Pomits, 2(2), 303-305.

Suaryana, N. (2016). Performance evaluation of stone matrix asphalt using indonesian natural rock asphalt as stabilizer. International Journal of Pavement Research and Technology, 9(5), 387392.

Suaryana, N., Subagio, B., Kosasih, D., \& Sjahdanurlirwan. (2014). Pengembangan model korelasi antara modulus resilien dengan modulus dinamis untuk campuran stone matrix asphalt. Jurnal Teknik Sipil ITB, 21(2), 171-178. 